\title{
膝関節側面撮影における 再撮影率隇少を目的とした補助具の提案
}

\section{嗅床技術}

論文受付

2012 年 10 月 3 日

論文受理

2013 年 8 月 2 日

Code No. 112

\author{
安田 優 ${ }^{1}$ 佐藤久弥 ${ }^{2}$ 大澤三和 ${ }^{1}$ 高橋寛治 ${ }^{1}$ \\ 野田主税 ${ }^{1}$ 崔 昌五 $^{1}$ 助崎文雄 $^{3}$ 中澤靖夫 ${ }^{2}$
}

\author{
${ }^{1}$ 昭和大学病院放射線部 \\ 2 昭和大学大学院保健医療学研究科診療放射線領域 \\ ${ }^{3}$ 昭和大学医学部整形外科学教室
}

\section{緒 言}

人体の中で最も大きい関節である膝関節は，回旋・転 がり・すべりといった複雑な運動をするため, 一生を通 して障害を受けやすく, 撮影頻度の高い関節の一つで ある1)、膝関節の正面像では，大腿骨と脛骨の内外側の 顆部，脛骨の内外側の高原と脛骨棘，関節の内外側 部，腓骨小頭が評価できる，それに対し側面像では， 膝蓋骨を側面からとらえ, 大腿膝蓋領域, 上膝蓋関節 包, 大腿四頭筋腱の評価が可能である

成書 ${ }^{5 \sim 7}$ によれば，膝関節側面像は側臥位で脛腓方向 撮影を行う，膝関節部の外側をカセッテにつけ，膝関節 を内角 120 度になるように屈曲してわずかに外旋する。

下腿の足方を 7 度上げる. X 線中心は膝蓋骨下端と後 方のくびれを結ぶ線の中心に垂直に入射する，当院に おいてもこの撮影法を取り入れており，その際に膝関節 がカセッテの中心になるようにし，下腿骨がカセッテ長
軸に平行になるようにレイアウトする。 また，再撮影の 基準は日本放射線技術学会 Quality Control プログラ ム $^{8)}$ (以下 $\mathrm{QC}$ プログラム)に基づき，内外顆のズレを $7 \mathrm{~mm}$ 以内としている.

膝関節側面撮影は，大腿骨内外顆を体表から目視ま たは触知するのが困難であるうえ，大腿骨内外顆の内 外旋と内外転の 2 軸の補正を行う必要がある。そのた め, 個人の技術や経験・感覚に依存する点が多く，骨撮 影領域でも難しい撮影法であるといえる。しかし，整形 外科領域では X 線検査のみで確定診断やフォローアッ プをすることもあり，その画像は患者の治療に影響する ため, 撮影者が異なっても臨床画像上の診断能が一定 となるような画像が要求される.

本研究は, 本学医の倫理委員会の許可のもと, 膝関 節側面撮影における補助具を作成し，再撮影率減少の 有用性を検討したので報告する。

\section{Proposal for an Auxiliary Tool Designed to Reduce Retake Rates for Lateral Radiography of the Knee Joint}

Yu Yasuda,${ }^{1 *}$ Hisaya Sato, ${ }^{2}$ Miwa Ohsawa, ${ }^{1}$ Kanji Takahashi, ${ }^{1}$ Chikara Noda, ${ }^{1}$ Syogo Sai, ${ }^{1}$ Fumio Sukezaki, ${ }^{3}$ and Yasuo Nakazawa ${ }^{2}$

${ }^{1}$ Division of Radiological Technology, Showa University Hospital

${ }^{2}$ Showa University Graduate School Medical Care Study Graduate Course Medical-examination Radiation Domain

${ }^{3}$ Department of Orthopaedic Surgery, Showa University School of Medicine

Received October 3, 2012; Revision accepted August 2, 2013

Code No. 112

\section{Summary}

The reproducibility of lateral radiography of the knee joint in the lateral position is low because patient positioning can be easily affected by passive rotation of the knee joint. We calculated the correction angle of the femoral external rotation and the lower leg elevation and developed our own auxiliary tool for obtaining a lateral view image. We were able to obtain, in a single attempt, an image with misalignment of the condyle limited to less than $7 \mathrm{~mm}$. Our tool also contributed to the reduction of the re-imaging rate, suggesting its usefulness in contributing to a lower re-imaging rate for lateral radiography of the knee joint.

Key words: auxiliary tool, radiology, knee joint

*Proceeding author 


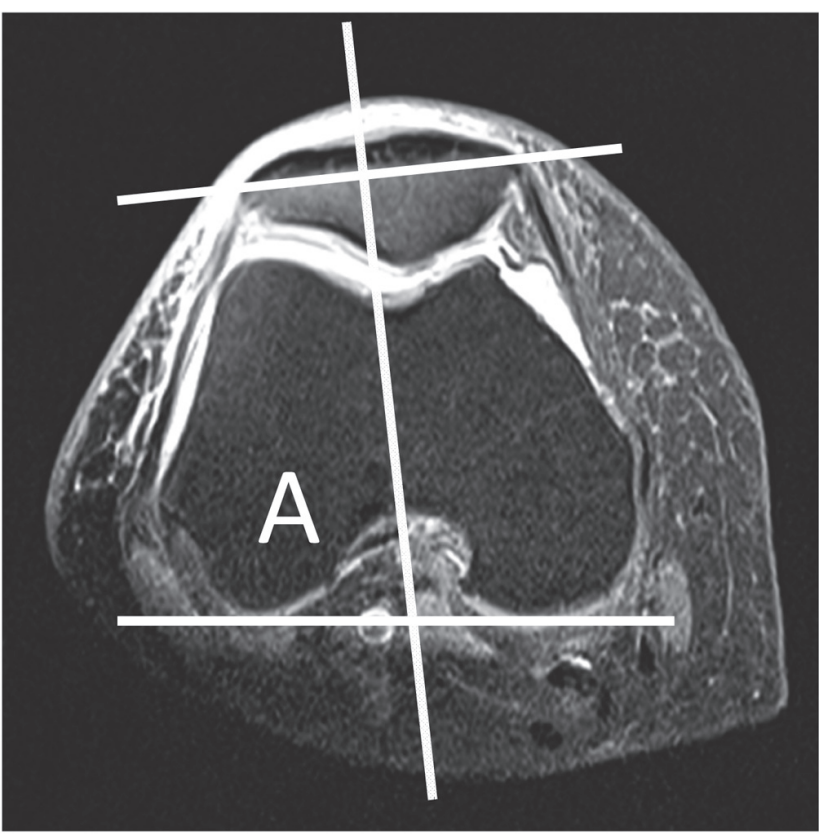

Fig. 1 MRI measurement angle.

Angle $\mathrm{A}$ is the angle formed between a line perpendicular to the patellar surface and a line connecting the posterior medial and lateral femoral condyles.

\section{1. 方 法}

膌関節の内側顆部後縁と外側顆部後縁を結ぶ線は後 傾しているが, 内側顆部前縁と外側顆部前縁の結ぶ線 は前傾している，膝関節側面像とは, 斜入する X 線束 が内顆と外顆の傾斜角を接線として投影することで関 節面が揃う撮影法である。

大腿骨内外顆の一致する傾斜角を求めるため, 膝関 節の磁気共鳴画像法 (magnetic resonance imaging: MRI) 画像の横断像と単純 $\mathrm{X}$ 線画像 (X-ray photograghy: XP)の正面像を用いて計測を行った。 MRI画像は SIEMENS 社製 MAGNOTOM avantoを使用した。MRI の撮像シーケンスは time of repeat : $4000 \mathrm{~ms}$, time of echo : $10 \mathrm{~ms}$, flip angle : 170, field of view : $180 \mathrm{~mm}$, matrix：256×256, slice thickness： 4 mm である.XPは日 立社製の X 線装置 UH-6FC-31E と富士フイルムメディ カル社製富士 imaging plate(IP) カセッテ CC を用いて撮 影を行い, FUJIFILM 社製 Fuji computed radiography SPEEDIA CS にて読み取りを行った。撮影条件は $60 \mathrm{kV}, 4 \mathrm{~mA}$ second (mAs), 撮影距離 100 とした。計 測の際にはFUJIFILM 社製画像保存通信システム (picture archiving and communication systems: PACS) SYNAPSEに転送した画像を用い，SYNAPSEの計測 ツールを使用した。

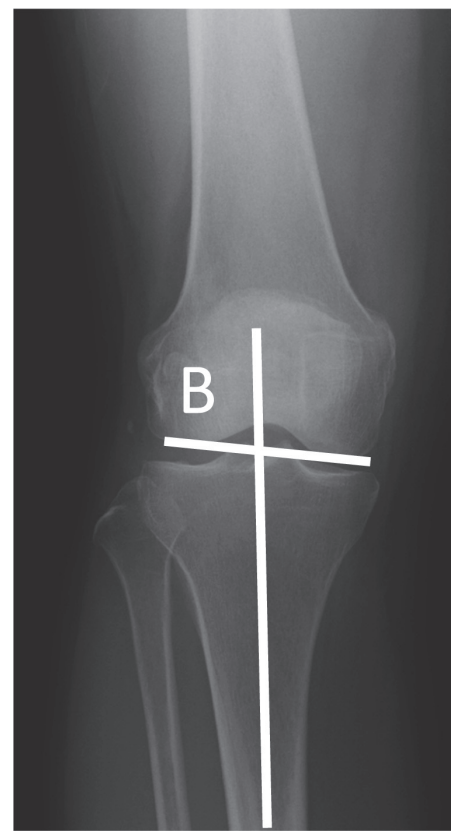

Fig. 2 XP measurement angle.

Angle B is the angle formed between the line connecting the medial and lateral femoral condyles and the lower leg axis.

\section{1-1 XP，MRI 画像における膝関節の計測}

QC プログラムから，膝蓋骨が大腿骨遠位端の内外 顆を結んだ線の中央に観察されるとき，膝関節は正面 像となる，膝関節が正面を向いた状態から，大腿骨後 方の内外顆を一致させる角度を求めるため, 膝蓋骨と 内外顆後面を同時に観察できる MRI 画像の横断像を使 用した，膝関節を正面位に整位する際，溙蓋骨に触る 指標となる 2 点(膝蓋鞁帯部両側の扁平なくぼみ：膝蓋 関節間隙に相当)を含む面を膝蓋骨面とした。横断像に て内外顆が最も広く描出される断面を選び，膝蓋骨面 に垂直な線と，大腿骨後方の内外顆を結ぶ線を引き， その二つのなす角(角 A)を計測した(Fig. 1)。さらに, 踵を上げることで大腿骨の内旋が補正され大腿骨下面 を一致させることができる。この踵を上げて大腿骨内外 顆が一致するときの角度を求めるため, XP の正面像 を用いて計測を行った。膝蓋骨正面位で正しく撮影 されているXPにて，大腿骨内外顆を結ぶ線と下腿 長軸の線を引き，その二つのなす角(角 B)を計測した (Fig. 2). 今回補助具作成のために MRI 画像とXPでの 計測の対象とした症例は，2012 年 1 月 1 日から 2012 年 4 月 30 日の期間に，膝関節の MRI と単純 X 線撮影の 検査を行った，骨折など異常所見のない 62 例である. 症例の内訳は男性 25 名, 女性 37 名, 平均年齢は 48 歳である。 


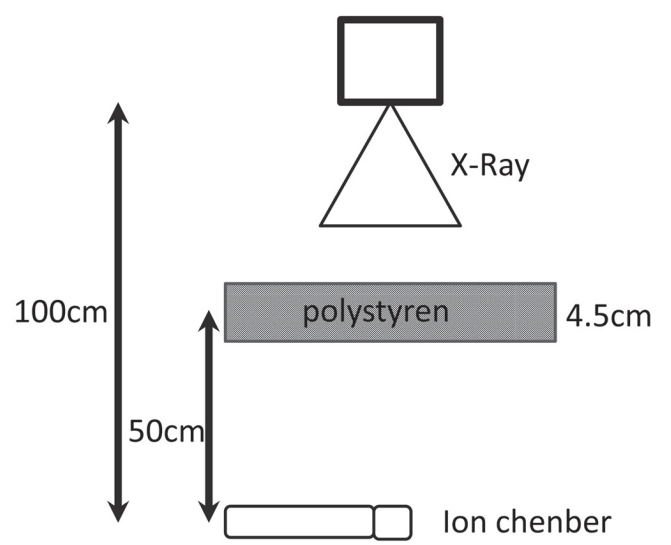

Fig. 3 Geometry during X-ray transmissivity measurement.

\section{1-2 補正角度の算出}

大腿骨内外顆の形状は矢状方向において内顆が外顆 より後方に長いため, 膝関節の正面像に対する 90 度側 面像は内旋位となる。 大腿骨の内外顆後面を一致させ る外旋方向の補正角を得るため, 90 度から計測した角 $\mathrm{A}$ を引き，外旋方向の補正角 $\mathrm{A}^{\prime}$ とした，外旋補正と同 様に, 90 度から角 $\mathrm{B}$ を引き，下腿を外転させる補正角 B’とした.

\section{1-3 補助具の作成}

算出した補正角度を基に，外旋方向と外転方向の二 つの角度をもつ補助具を作成した，また，補助具の表 面に基準となる膝関節のシェーマを表記した，補助具 のサイズは四切サイズと同じとした。

補助具の材料としたポリスチレンの X 線透過率につ いて計測を行った．X線アナライザには Radcal 社製 ACCU-GOLD, 半導体検出器には Radcal 社製 AGMSD 型マルチセンサを使用した。ポリスチレンの厚さは, 最大となる $4.5 \mathrm{~cm}$ のものを使用した．まず当院の臨床 で使用している膝関節撮影の条件 $[60 \mathrm{kV}, 4 \mathrm{mAs}$, 照 射野は四切サイズ(縦 $33 \mathrm{~cm} \times$ 横 $28 \mathrm{~cm}$ ) とする]にて撮 影距離 $100 \mathrm{~cm}$ の位置に扮ける空気吸収線量を 3 回測 定した，次にポリスチレン自体の X 線透過率を知るた め, 後方散乱を避けてポリスチレンをX $\mathrm{X}$ 線管と検出器 の間の中空に固定した，そのうえで同じ撮影条件で空 気吸収線量を 3 回測定した。測定時のジオメトリを Fig. 3 に示す.

\section{1-4 補助具使用前後のズレ幅, 再撮影率の比較}

作成した補助具の有用性を検討するため, 次に示す 項目について, 補助具使用前後で比較を行った。 な お, 今回補助具使用の対象とした膝関節は, 側臥位の 肢位が可能で, femorotibial angle(FTA：膝外側角)が

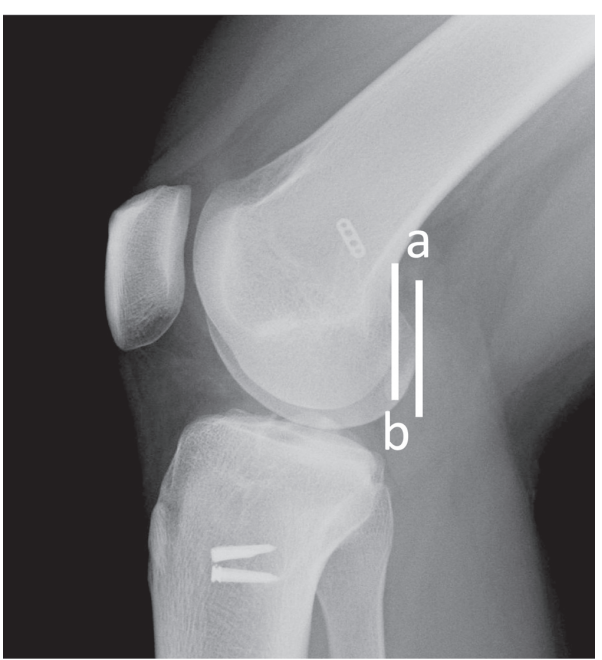

Fig. 4 Lateral deviation of medial and lateral condyles.
(a) Medial condyle

(b) Lateral condyle

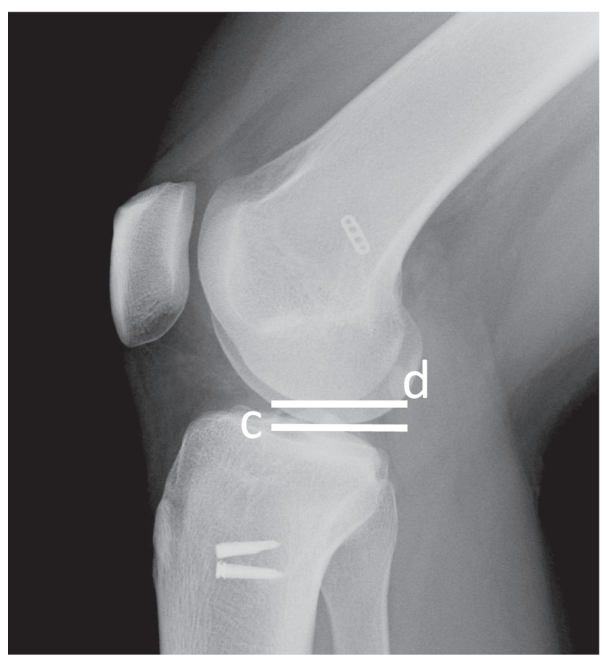

Fig. 5 Longitudinal deviation of medial and lateral condyles.

(c) Medial condyle

(d) Lateral condyle

170 度以下の外反膝 $(\mathrm{X}$ 脚 $)$ や 180 度以上の内反膝 $(\mathrm{O}$ 脚)を除外した正常膝関節のみとした。

\section{1-4-1 内外顆のズレ幅の比較}

内顆と外顆のズレ幅について, 大腿骨の横方向のズ レと縦方向のズレの二つに分けて比較を行った，横方 向のズレは, 画像の長軸に平行な線で内顆 (a) と外顆 (b)の接線を引き, その距離とした(Fig. 4). 同じよう に, 縦方向のズレは画像の短軸に平行な線で内顆 $(\mathrm{c})$ と 外顆(d)を引き, その距離とした(Fig. 5).

また, 比較の対象とした症例は, 補助具使用前は 2012 年 6 月 1 日〜 30日に補助具を用いず撮影した症例 54 例 (男性 23 名, 女性 31 名, 平均年齢 47.1 歳), 補助 


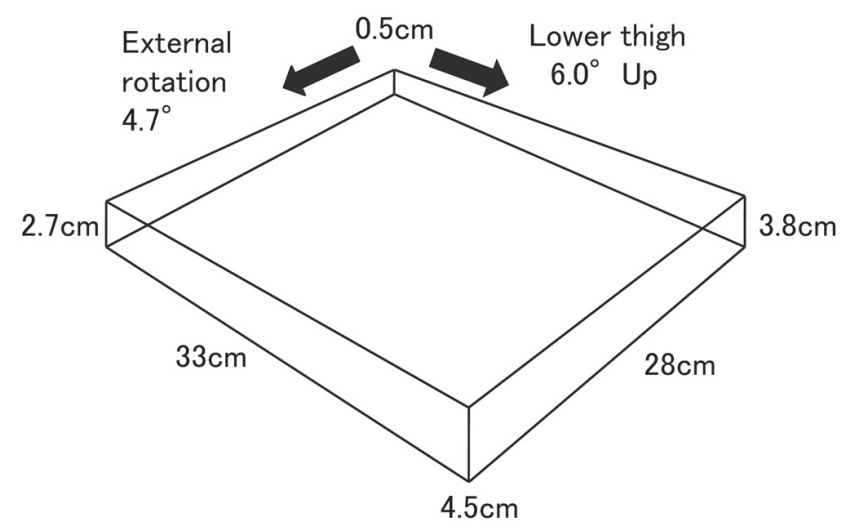

Fig. 6 Dimensions of adapter, calculated from measurements. Double-angled with $4.7^{\circ}$ in the extorsional and $6.0^{\circ}$ in the abductional direction.

具使用後は 2012 年 7 月 9 日以降に補助具を使用して撮 影した 54 症例(男性 21 名, 女性 33 名, 平均年齢 53.7 歳)を対象とした。

\section{1-4-2 再撮影率の比較}

膝関節側面撮影の再撮影率について比較を行った。 2012 年 7 月 1 日〜 31 日に補助具を用いず撮影した 122 症例と, 2012 年 8 月 1 日〜 31 日に補助具を用いて撮影 した 94 症例のうち, 何症例の再撮影が発生したかを調 べ，その割合を算出した。 また，その再撮影が内旋過 多なのか外旋過多なのかを調べた。

\section{2. 結 果}

\section{2-1 XP，MRI 画像における膝関節の計測}

外旋方向の計測角 $\mathrm{A}$ は平均 85.3 度, 外転方向の計 測角 B は平均 84.0 度であった。

\section{2-2 補正角度の算出}

膝関節の側面像を得る，外旋方向の補正角 A'を 4.7 度，外転方向の補正角 B’を 6.0 度とした。

\section{2-3 補助具の作成}

補助具は, 角 $A^{\prime}$ と角 B' のダブルアングルをもつよ うにし，ポリスチレンを用いて作成した(Fig. 6，7)。 な お, 今回作成した補助具は四切サイズ(縦 $33 \mathrm{~cm} \times$ 横 $28 \mathrm{~cm}$ )の IP を基準としている.

また，今回補助具の材料に用いたポリスチレンは, 使用の有無による空気吸収線量差が $0.0018 \mathrm{mGy}$ とな り, 約 96\%の透過率であった(Table 1).

\section{2-4 補助具使用前後の比較}

\section{2-4-1 内外顆のズレの比較}

補助具を使用して撮影した膝関節について, 使用前

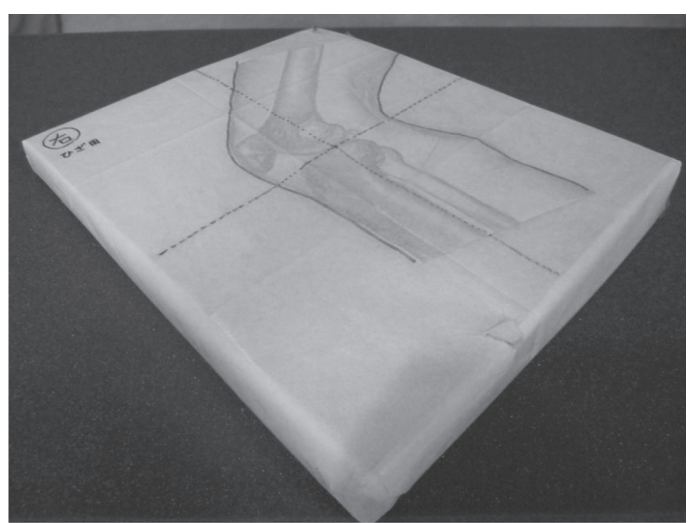

Fig. 7 The adapter.

Created using polystyrene based on dimensions calculated from measurements and marked with knee joint schema on the surface.

Table 1 Change of dose

\begin{tabular}{|c|c|c|}
\hline & $\begin{array}{c}\text { Polystyrene } \\
\text { nothing (mGy) }\end{array}$ & $\begin{array}{c}\text { Polystyrene } \\
\text { existence (mGy) }\end{array}$ \\
\hline 1 & 0.0432 & 0.0415 \\
\hline 2 & 0.0432 & 0.0413 \\
\hline 3 & 0.0432 & 0.0414 \\
\hline Average & 0.0432 & 0.0414 \\
\hline X-ray trancemittance & \multicolumn{2}{|c|}{$96 \%$} \\
\hline
\end{tabular}

Change of dose was investigated with no polystyrene.

の結果を, 横方向のズレ, 縦方向のズレ, 使用後の結 果を，横方向のズレ，縦方向のズレにそれぞれ分けて 比較した．使用前後のズレを箱ひげ図を用いて横方向 (Fig. 8) と, 縦方向(Fig. 9)に分けて示す. 横方向のズレ は平均土標準偏差が $3.2 \mathrm{~mm} \pm 2.1$ から $1.5 \mathrm{~mm} \pm 1.3$, 縦 方向のズレは $2.7 \mathrm{~mm} \pm 1.7$ から $1.0 \mathrm{~mm} \pm 1.1$ へと減少した (Table 2)。なお，この結果に関しては，ウィルコクソン 検定を行い，P<0.05 となった。補助具を使用した膝関 節では, $7 \mathrm{~mm}$ 以内のズレの中でも 54 例中 25 例が内旋 傾向，11 例が外旋傾向，18 例は内外顆のズレが $1 \mathrm{~mm}$ 以下で内外旋の判別がつかないものであった(Table 2).

\section{2-4-2 再撮影率の比較}

補助具使用前後の再撮影率の結果を Table 3 に示 す。再撮影率は $10.7 \%$ から $3.2 \%$ へ減少した。補助具 使用前の再撮影の内訳は外旋過多 9 例，内旋過多 4 例 であった。使用後の再撮影の内訳は外旋多過 1 例，内 旋多過 2 例であった(Fig. 10).

\section{3. 考 察}

膝関節側面撮影では内外顆を一致させるために外旋 


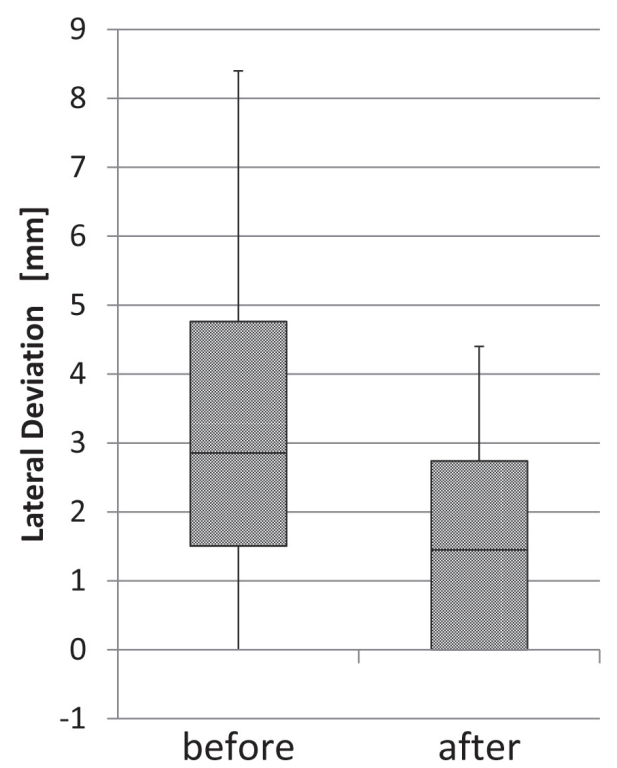

Fig. 8 Variability in lateral deviation of medial and lateral condyles before and after adapter use.

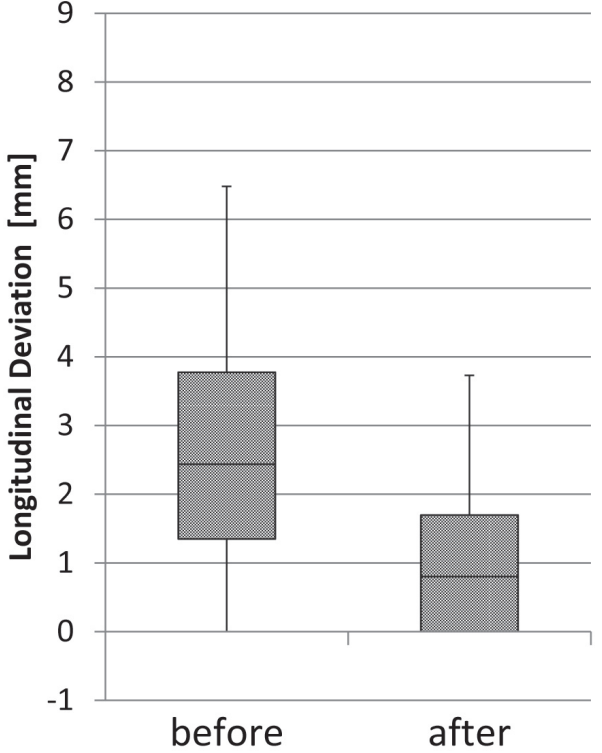

Fig. 9 Variability in longitudinal deviation of medial and lateral condyles before and after adapter use.

Table 2 Comparison of before and after use

\begin{tabular}{lccccc}
\hline \hline & $\begin{array}{c}\text { Lateral gap } \\
(\mathrm{mm})\end{array}$ & $\begin{array}{c}\text { Longitudinal gap } \\
(\mathrm{mm})\end{array}$ & $\begin{array}{c}\text { Excessive internal } \\
\text { rotation (cases) }\end{array}$ & $\begin{array}{c}\text { Gaps less than } \\
1 \mathrm{~mm}(\text { cases })\end{array}$ & $\begin{array}{c}\text { Excessive external } \\
\text { rotation (cases) }\end{array}$ \\
\hline Before use & $3.2 \pm 2.1$ & $2.7 \pm 1.7$ & 21 & 7 & 27 \\
After use & $1.5 \pm 1.3$ & $1.0 \pm 1.1$ & 25 & 17 & 13 \\
\hline
\end{tabular}

The magnitude of medial and lateral condyle deviation in the longitudinal and lateral directions, the number of cases with excessive intorsion, the number of cases with deviation of $1 \mathrm{~mm}$ or less, and the number of cases with excessive extorsion were compared before and after use of the adapter.

Table 3 Retake rate

\begin{tabular}{lccc}
\hline \hline & $\begin{array}{c}\text { Number of } \\
\text { total cases }\end{array}$ & $\begin{array}{c}\text { Number of } \\
\text { retake cases }\end{array}$ & $\begin{array}{c}\text { Retake rate } \\
(\%)\end{array}$ \\
\hline Before use & 122 & 13 & 10.7 \\
After use & 94 & 3 & 3.2 \\
\hline
\end{tabular}

Comparison of number of cases where retakes were required before and after adapter use.

補正・外転補正を行う必要がある，当院では従来，側臥 位にてカセッテの上に直接膝関節を置き, 個々の感覚で 側面像を触知して大腿骨の内顆と外顆を合わせていた が, 再撮影率が 10.7\%と高い值にあった。

今回作成した補助具を使用して撮影を行うと, 従来 の触知によるポジショニングに比較し, 膝関節の 4.7 度 外旋と, 6.0 度外転で角度が一定となり, 撮影者による 感覚の差の違いが除外され，整位しやすくなったため 内外旋・内外転のズレが改善し, 再撮影が減少したと考

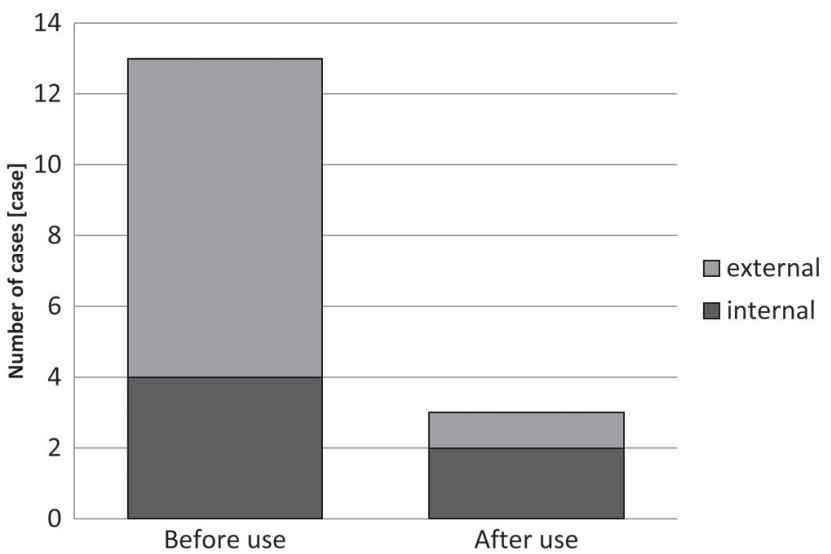

Fig. 10 Breakdown of retakes.

Classified into excessive intorsion and excessive extorsion.

える。また，今回補助具を使用したことで，大腿骨の内 顆と外顆のズレが $1 \mathrm{~mm}$ 以下になった症例が 54 例中, 7 例から 17 例となり，大きな改善がみられた。

また，再撮影の内容として，使用前では 122 例中 13 
例の再撮影枚数のうち, 外旋過多 9 例だったが, 使用 後では 94 例中 3 例の再撮影枚数中, 内旋過多が 2 例 であった。これは，使用前では梅木ら999の言うように, 側臥位にした際の骨盤の整位による補正が十分でなく 骨が外旋してしまっていたためと考えられる。使用後で は，補助具による補正が行われているが，その補正角 度は骨のみの計測で求められており脂肪や筋肉の皮下 組織の厚さを考慮していないため, 補助具の上に膝を 乗せると, 皮下組織の厚みの分だけ内旋傾向となるた めと考えられる。ただし，QC プログラム ${ }^{8)}$ における再撮 基準内でのズレであることから, 本補助具は有効価值 が高いと考える。

補助具のX線減弱率について, 今回の測定では $0.0018 \mathrm{mGy}$ の変化があり約 $96 \%$ O 線の透過があっ た．矢田らの研究10)で， $3 \mathrm{~mm}$ 厚のカーボン板で $96 \%$ の X 線透過率であり, 臨床画像への影響はほぼないとい う結果が得られており，それとほぼ同じポリスチレンの 96\%の X 線透過率であるため, 臨床画像への影響は少
ないと考えられる。したがって，本研究では素材が撮 影条件に与える影響は考慮しないものとする。

\section{4. 結 語}

膝関節側面撮影は，膝関節の他動回旋の影響を受け やすく整位が困難で再撮影率の高い撮影法であった。 しかし今回，側面像を得るために必要な大腿骨の外旋・ 外転の補正角度を求め, 補助具を作成・使用したこと で，側臥位の肢位が可能であれば，一度の撮影で内外 顆のズレが $7 \mathrm{~mm}$ 以内の側面像を得ることができた。 ま た，再撮影率の低減にも寄与することができた。今回 作成した補助具は，膝関節側面撮影に有用であると示 唆された。

\section{謝 辞}

本研究に際し，御指導いただきました昭和大学統括 放射線技術部長はじめ, 昭和大学病院放射線部技師室 諸氏に厚く御礼申し上げます。

\section{参考文献}

1) 守屋茂繁, 北原 宏, 富田勝郎. 整形外科放射線診断学 原書第 3 版. 南江堂, 東京, 2004: 239-241。

2) 鳥巣岳彦, 国分正一. 標準整形外科学 第 9 版. 医学書 院，東京，1993: 560-567.

3）平田幸男. 分冊 解剖学アトラス I 第 6 版. 文光堂, 東 京, 2011: 192-203.

4）久保俊一, 齋藤知行. 膝の外科 I 原著第 4 版. 金芳堂, 京都, 2007: 7-11.

5) 安藤英次, 高倉義典. 図解 下肢撮影法 第 1 版. オーム 社, 東京, 2010: 53-66.

6）小塚隆弘, 稲邑清也, 山下一也, 他. 診療放射線技術上
巻 第 12 版. 南江堂, 東京, 2009: 147-148.

7）堀尾重治. 骨・関節 X 線写真の撮りかたと見かた 第 7 版. 医学書院, 東京, 2008: 264-269.

8）日本放射線技術学会専門委員会. 一般撮影における合格基 準。放射線技術 QC プログラム，日本放射線技術学会 1992: 59-60.

9) 梅木智子, 葉山和弘, 渡辺雅弘。膝関節側位撮影における 形態解剖学的検討. 日放技学誌 1996; 52(10): 1402.

10）矢田麻子，是川紗江，谷川基務，他．フラットパネルディテ ク夕 (FPD) 対応型小児撮影台の開発と評価. 日本放射線技 術学会近畿部会雑誌 2011; 17(1): 90. 